\title{
AN ANALYSIS OF DEIXIS USING “BEAUTY AND THE BEAST” MOVIE SCRIPT
}

\author{
Elisa Fadlilah ${ }^{1}$, Rika Septyani ${ }^{2}$ \\ ${ }^{1}$ IKIP Siliwangi \\ ${ }^{2}$ IKIP Siliwangi \\ 1elisafadlilah2@gmail.com, ${ }^{2}$ rikaseptyani10@gmail.com
}

\begin{abstract}
This study deals with the English deixis. The objectives of this study are to analyze type of deixis and to find out the frequency of each deixis in the movie entitled Beauty and The Beast. This study was conducted by using descriptive qualitative research. The source of data was taken from the movie script of Beauty and The Beast. Documentary technique is used in collecting data. The findings showed that there are three types of deixis found in the Beauty and The Beast movie script and there are nine frequencies of deixis, namely person deixis in greater occurrences than another. Type of person deixis is used 128 times or $(84,21 \%)$, which consists of first person used 53 times or $(34,86 \%)$, second person used 52 times or $(34,21 \%)$, and third person used 23 times or $(15,13 \%)$. The next, spatial (place) deixis is used 12 times or $(7,89 \%)$ and the last, temporal (time) deixis is used 12 times or $(7,89 \%)$ which consists of present used 5 times or $(3,28 \%)$, past used 5 times or $(3,28 \%)$, future used 2 times or $(1,31$ $\%)$. The least frequently used by the Beast in Beauty and the Beast Speech film`s dialogue was first person deixis used 53 times or $(34,86 \%)$.
\end{abstract}

Keywords: Pragmatic, Movie, Deixis

\section{INTRODUCTION}

Pragmatics is the branch of linguistics that studies language or code that instructed by the speaker or writer, and understood by the listener or reader. According to (Yule, 1996) the study of contextual meaning conveyed by a speaker or writers, and received by a hearer or reader. (Levinson, 1983) Pragmatics is a learning relationship between languages and contexts that are grammaticalized, or encrypt in the structure of language.

The word can be interpreted its meaning based on the context of called deictic or deixis. Deixis is used to search for actions in a time frame relative to the present.

(Yule, 1996) stated "Deixis is clearly a form of refers to that is bind to the speaker's context, with the most basic distinction between deictic expressions being 'near speaker' agains 'away from speaker"'. Therefore deixis is one of a branch in linguistic that is part of pragmatics to refer to a meaning depending on the context, referenced by speakers and influenced by the conversation.

According to (Grundy, 2008) Deictics are a closed class; there is a limited set of such words to which we cannot (readily) add. As with other closed class type, deictics are semantically imperfect. According to the three fundamental semantic criteria that are an essential part of every framework we knowledge: person, place and time. 
The writers observed a transcript of a movie entitled "Beauty and the Beast", some of the characters in the movie, the writers" only focused on dialogue "The beast" and the material used are deixis.

The reason of a writers uses a transcript of a movie because the movie is interesting therefore the writers is interested in analyzing and examining the film and the language used in dialogue easier to understand (non - formal language) by the reader or viewer of the movie. Another reason why the use of deixis because to find out what kinds of deixis.

\section{Pragmatic}

According to (Yule, 1996) state "Pragmatics is concerned with the study of meaning as communication by a speaker (or writers) and interpreted by a listener (or reader)".

(Levinson, 1983) Pragmatics is a learning relationship between languages and contexts that are grammaticalized, or encrypt in the structure of language.

\section{Deixis}

"Deixis is a technical term (from Greek) for one of the most basic things we do with utterences. It means 'pointing' via language" (Yule, 1996). Types of deixis based on Yule they are person deixis, spatial deixis and temporal deixis.

In line with (Grundy, 2008) Deictics are a closed class; there is a limited set of such words to which we cannot (readily) add. As with other closed class type, deictics are semantically imperfect. According to the three fundamental semantic criteria that are an essential part of every framework we knowledge: person, place and time.

According to Bühler (Buhler, 2011, p. 67) cited in (Dylgjeri \& Ledia, 2013) "there is a deictic centre that consists of I, Here and Now. As a result there are three main categories of deixis: 1 . Person deixis, used to point to objects (it, these, those books) and people (her, him, them, those students) 2. Spatial deixis, used to point to a location (here, there, close to) 3. Temporal deixis, used to point to a time (now, then, next week, last month) in order to interpret all these deictic expressions we must know which person, time and place the speaker has in mind. There is a great difference on what is close to the speaker (this, here, now) and what is distant (that, there, then). We can also realize whether there is a movement away from the speaker (go) or there is a movement towards the speaker (come)".

\section{Person Deixis}

Person deixis is used to point people. According to Levinson (1983: 69) cited in (Tullah, 2015) person deixis is divisible into three kinds. They are first person, second person and third person.

Table 1.1 (types person deixis)

\begin{tabular}{ccc}
\hline Pronoun & Singular & Plural \\
\hline $1^{\text {st }}$ person & $\mathrm{I} / \mathrm{me}$ & $\mathrm{We} / \mathrm{us}$ \\
$2^{\text {nd }}$ person & You & You \\
$3^{\text {rd }}$ person & $\mathrm{He} / \mathrm{him}$, she/ her, it & They/ them \\
\hline
\end{tabular}

(Cruse, 2000: $320 \&$ the researcher's data, 2000) 


\section{Spatial Deixis}

"Place Deixis is also described as Spatial Deixis, where the relative location of people and things is being indicated. It usually is expressed in: this, these, that, those, there and here. The absolute reference to placing the search for an object or a person in a certain longitude and latitude line, while a relational reference looks for people and places in respect of each other and the speaker (Cummings 2005, p.26) quoted in (Gjergji, 2015).

\section{Temporal Deixis}

"Time Deixis is also called as temporal deixis. Rankema (1993, p. 79) cited in (Gjergji, 2015) stated time deixis is a reference to time relative to a temporal reference point and it is typically the moment of utterance. These language resources are the adverbs of time: yesterday, tomorrow, now, then."

\section{METHOD}

The type of this research is descriptive qualitative research, according to (McMillan \& Schumacher, 2001) qualitative research uses a case study design meaning that the data analysis focuses on one phenomenon, which the writers select to comprehend in depth regardless of the number of sites or participant for the study. In which the method are used to collects the data, classifies and analyzes them, and then draw the conclusion from the analyzed data. In this study, the writers aims at classifying the forms of deixis used on Beauty and The Beast Movie to describe the types of deixis and the reference of person, spatial and temporal deixis used in Beauty and The Beast movie. Focusing on the second person (The Beast), the data source of the research is a movie script. The writers takes the data from the movie script of Beauty and The Beast which produced by Stephen Chbosky and Evan Spiliotopoulos, 2016.

In collecting data, the writers uses document method. The steps of collecting data are as follows: (1) Watching the original movie of Beauty and The Beast, (2) Reading the script of Beauty and The Beast movie, (3) Selecting and collecting the data, (4) Classifying the types of deixis in Beauty and The Beast movie manuscript, (5) Coding the data, (6) Drawing the conclusion and suggestion based on the data analysis.

\section{RESULTS AND DISCUSSION}

\section{Results}

This sub-heading presents the findings, related to the types of deixis which are found in Beauty and the Beast movie script.

\section{Types of Deixis Found in Beauty and the Beast Movie Season}

Deixis is a part of remark in the form of words or phrases, used for pointing something to make communication clearer and their interpretation depends on the speaker, place, and time of remark. Levinson (1983: 54) cited in (Tullah, 2015) states that deixis interest the ways in which language encode the features of the context of remark or speech event. In this study, the writers found 152 deitic categories. However, in the presentation, the writers exemplifies one case among the variations that are found in the data.

The three types of deixis include Person, Spatial, and Temporal each of which is presented as follows: 


\section{a. Person Deixis}

Person deixis is an utterance that is produced by the speaker in the speech event. In a conversation, the subject does not always refer to one person but may refer to some people. Below is an example of a conversation containing person deixis,

The Beast : "I (1) received eternal damnation for one."

The Beast : "Who are you (2)?"

The Beast : "He (3) stole a rose."

The Beast : "She's (4) the daughter of a common thief."

The writers found 128 deitic categories of person deixis, including first, second, and third person deixis. The followings are the data from data corpus.

\section{First Person Deixis}

The first person deixis is the grammaticalization of the talker's reference to himself. According to Yule (1966: 10) cited in (Tullah, 2015) first person deixis can be marked with a pronoun (I/my, we/us). In our data corpus, we found 6 types of first person deixis, namely I, $\boldsymbol{m e} \boldsymbol{e}, \boldsymbol{m y}$, we, us and our. The first type is used in the position of object. Please see the following excerpt.

[1] The Beast : "I received eternal damnation for one."

In the text, the beast said that I received eternal damnation. The word "I" is a subject pronoun from the speaker himself and it is a possessive pronoun of the speaker. Here, the speaker wants the addressee to give the thing belong to the speaker. So, Pronoun "I" can be categorized into first person deixis.

\section{Second Person Deixis}

Second person deixis is deictic reference that mention to addressee. According to Levinson, (1983: 62) cited in (Tullah, 2015) second person deixis can be identified into the words (you, your, yours, yourselves).

In our data corpus, we found 6 types of second person deixis, namely you, your, Lumiere and Belle. Second person deixis occurs in the middle and initial position of an utterance that is in the position of object and subject. As such, it can be seen in excerpt below.

[2] The Beast : "You took his place."

If we analyze the following sentence, the beast says "You took his place." that have meaning the beast told "you" for replace. On the sentence, the word you meaning second person deixis, the word (you) is categorized into a deixis of second person because it refers to the addressee.

\section{Third Person Deixis}

Third person deixis encodes of references to person and entities that are neither speaker nor addressee of the remark in question. According to Levinson (1986: 69) cited in (Tullah, 2015) third person deixis is identified into remark (he/his, she/her, and they/them) and the object like "him, her, it and them". In addition, third person may also identify in pronoun and proper name.

In my data corpus, the writersfound 6 types of third person deixis, namely he, him, his, her, she and them. Please see the following excerpt.

[3] The Beast : "He stole a rose." 
The sentence, "beast" says the second person "He stole a rose." the word "he" in statement Beast refers to father's Belle, and he included into the third person deixis because it refers to person of the utterance in question.

\section{b. Spatial Deixis}

Spatial deixis (Place deixis) focus on the place where the speech event occurs and deals with the distance. The utterance ("You gave her a bedroom?") is one of example of place deixis. Place deixis can be marked of demonstrative pronouns such as; 'this' and 'that', and also can be marked of demonstrative adverbs of place such as; 'here' and 'there'.

In our data corpus, the writers found 9 types of place deixis, namely bedroom, here, room, village, Paris, ballroom, there, coming and out. The first is used in the position of adverb of place. Please see the following excerpt.

\section{[4] The Beast : "You gave her a bedroom?"}

In this sentence, the Beast says "You gave her a bedroom?" Meaning "Beast" has given bedroom. Which meant "bedroom" in the text is the place. The word "bedroom" that found in sentence [4] is spoken by The Beast. Based on the context of sentence above, it points the place that speech even occurs. Place deixis focus on the place where the speech event occurs. So, the word (bedroom) can be included into spatial deixis (Place deixis).

\section{c. Temporal Deixis}

Temporal or time deixis concerns with the encoding of temporal points in the speech event. According to Levinson (1983) cited in (Tullah, 2015) stated that deictic refers to points locating time, which the time axis used the moment of utterance "you" as a reference, is called time deixis. In addition, we can say the word (pointing time). At the time axis, we can identify several elements such as, before "you" e.g. yesterday and before, moment of utterance "you" e.g. now and today, and after "you" e.g. soon and tomorrow. Present time included now, today, etc. Past time included then, yesterday, last week, etc.

In this study, the writers found 12 deitic categories of temporal deixis, including present time, past time, and future time. The following are the data from data corpus.

\section{Present Time Deixis}

The present time type is the time axis used the moment of utterance "you". The present time is used for pointing time that is happening on the conversation. In our data corpus, we found 2 types of present time, namely now and tonight. Please see the following excerpt.

\section{[5] The Beast : "Now, do you still wish to take your father's place?"}

The writers found the phrase "now" in the conversation [5]. It is spoken by the beast. Belle is the speaker at that event. The phrase "now" is deitic expression because it points, duration when speech events happen and the time used the moment of utterance "you". So, it can be categorized into present time deixis.

\section{Past Time Deixis}


The past time type is the time axis used before of utterance "you". The past time is used for pointing time that has occurred on the conversation. In our data corpus, we found 3 types of past time, namely years, coming back and last time. Please see the following excerpt.

[6] The beast : "At least I got to see you one last time."

In the sentence the beast said "At least I got to see you one last time." The word "last time" in conversation [6] is deitic expression and refers to duration in past time. With feature in word "I see ....." after the word last time and "was" is to be for past tense. So, the word "last time" can be included into past time deixis.

\section{Future Time Deixis}

The future time type is the time axis used after of utterance "you". The future time is used for pointing time that will occur in the future on the conversation. In our data corpus, we found 2 types of future time, namely one day and would. Please see the following excerpt.

[7] The beast : "It's foolish, I suppose, for a creature like me to hope that one day he might earn your affection."

The writers found the phrase "one day" in the conversation [7]. It is spoken by The Beast. The phrase "one day" is deitic expression because it points; duration when speech events happen and the time used after of utterance "you". Here, the speaker wants the addressee to look something to the future. So, it can be categorized into future time deixis.

The Frequency types of deixis found by writers in "the beauty and the beast" movie season. The complete results of the percentage can be seen in table 2.1

Table 2.1 Frequency of occurrence of Deixis types

\begin{tabular}{cccc}
\hline Types of Deixis & Frequency & Percentage & Total \\
\hline Person Deixis & & $84,21 \%$ & 128 \\
- First Person & 53 & $34,86 \%$ & 53 \\
- Second & 52 & $34,21 \%$ & 52 \\
$\quad$ Person & & & \\
• Third Person & 23 & $15,13 \%$ & 23 \\
Spatial Deixis & 12 & $7,89 \%$ & 12 \\
Temporal Deixis & & $7,89 \%$ & 12 \\
- Present & 5 & $3,28 \%$ & 5 \\
- Past & 5 & $3,28 \%$ & 5 \\
- Future & 2 & $1,31 \%$ & 2 \\
\hline
\end{tabular}

Based on the result above, the writers found person deixis in greater occurrences than another. Type of person deixis is used 128 times or $(84,21 \%)$, which consists of first person used 53 times or $(34,86 \%)$, second person used 52 times or $(34,21 \%)$, and third person used 23 times or $(15,13 \%)$. The next, spatial (place) deixis is used 12 times or $(7,89 \%)$ and the last, temporal (time) deixis is used 12 times or $(7,89 \%)$ which consists of present used 5 times or $(3,28 \%)$, past used 5 times or $(3,28 \%)$, future used 2 times or $(1,31 \%)$. 


\section{Discussion}

In discussion, the writers try to discuss the findings from the movie entitled "The Beauty and the Beast" based on the theory Levinson (1983). (Levinson, 1983) states that "there are five kinds of deixis, they are: person deixis, place deixis, time deixis, discourse deixis, and social deixis." The writers focus on three kinds of deixis generally occurs in Beauty and the Beast movie script, namely person deixis, spatial deixis, and temporal deixis.

In this discussion, the writers discussed about generalized person deixis firstly. The writers found some utterance, like "I received eternal damnation for one." The word (I) is categorized into person deixis because pronoun (I) refers to speaker himself as first person. The writers also found some utterance, like "You took his place." The following, the word (you) is included into person deixis because pronoun (you) refers to second person or addressee. The last "He stole a rose." The word (he) is person deixis because pronoun (he) refers to third person who does not correspond to any specific participant-role in the speech event.

The second is spatial deixis. The writers found the utterance, like "Stay there! I'm coming." The word "there" is categorized into spatial deixis because based on the context of sentence above; it points the place that speech even occurs. Place deixis focus on the place where the speech event occurs and deal with the distance.

The third is temporal deixis. In my data corpus, the writers found the utterance "Now, do you still wish to take your father's place?" the word "now" is categorized into temporal deixis because it refers to duration of speech event in present time. The utterance, like "At least I got to see you one last time." The word "last time" is deitic expression and refers to duration in past time. The last utterance "It's foolish, I suppose, for a creature like me to hope that one day he might earn your affection." The word "one day" is deitic expression and refers to duration in future time.

\section{CONCLUSION}

After the writers observed a transcript of a movie entitle Beauty and the Beast. The writers found types of deixis in Beauty and the Beast movie script as follows;

a. Person deixis: I, me, my, we, us, our, you, your, Lumiere, Belle, he, him, his, her, she and them.

b. Spatial deixis: bedroom, here, room, village, Paris, ballroom, there, coming and out.

c. Temporal deixis: now, tonight, years, coming back, last time, one day and would.

Here, it is the data percentage of deixis usage in Beauty and the Beast movie script. The person deixis is the one which reached great level than another, means it was used by 128 times or $(84,21 \%)$, which consists of first person used 53 times or $(34,86 \%)$, second person used 52 times or $(34,21 \%)$, and third person used 23 times or $(15,13 \%)$. The next, spatial (place) deixis is used 12 times or $(7,89 \%)$ and the last, temporal (time) deixis is used 12 times or $(7,89 \%)$ which consists of present used 5 times or $(3,28 \%)$, past used 5 times or $(3,28 \%)$, future used 2 times or $(1,31 \%)$.

\section{ACKNOWLEDGMENTS}

We are very grateful to the college staff who have trusted us to create a journal.

We would like to thank you to our supervisor Mr. Yana, S.Pd.,M. Hum. who has helped and inspired the creation of this journal. Thank you to Mr. Iman Santoso, S.Pd.,M.Hum. who has 
helped complete this journal and also thanks to all friends who have supported us so that we can complete the journals we created and can publish.

\section{REFERENCES}

Dylgjeri, \& Ledia. (2013). Deixis in Modern Linguistics and Outside. MCSER-CEMASSapienza University of Rome, 2. Retrieved from http://www.mcser.org/journal/index.php/ajis/article/viewFile/110/266

Gjergji, S. (2015). A pragmatic analyses of the use of types of deixis in poetry and novels of the author Ismail Kadare The importance and complexity to the pragmatic process concerning the different realities evoked in social interaction, communication and language. Academicus - International Scientific Journal, (12), 134-146. Retrieved from http://www.academicus.edu.al/nr12/Academicus-MMXV-12-134-146.pdf

Grundy, P. (2008). Doing Pragmatics. UK: Hodder Education.

Levinson, S. (1983). Pragmatics. University Press.

McMillan, J. ., \& Schumacher. (2001). Reseacrh in Education (Fifth). New York: Longman. Tullah, R. (2015). An Analysis of Deixis Found in Spongebob Movie Script.

Yule, G. (1996). Pragmatics. New York: Oxford University Press. 